\title{
PCR based prevalence study of Francisella tularensis in Kharkiv, Dnipropetrovsk, and Mykolaiv oblasts during 2015-2018
}

\author{
Oksana Borysivna Zlenko ${ }^{1}$, Gennadiy Evgenievich Tkach², Anna Borysivna Sukhorukova², \\ Lyudmila Vitaliivna Kylypko ${ }^{2}$, Lubov Stepanivna Machota ${ }^{2}$, Oleksandr Stefanovych \\ Ignatenkov $^{3}$, Kateryna Volodymyrivna Vinokurova ${ }^{3}$, Galyna Rostyslavivna Shamychkova ${ }^{4}$, \\ Oleksandr Pymonovych Shtepa ${ }^{4}$, Valentyna Gennadievna Rezvykh ${ }^{4}$, Julia Schwarz ${ }^{5}$, \\ Angela Duerr ${ }^{5}$, Claudia Popp ${ }^{5}$, Heiner von Buttlar ${ }^{5}$, Roman Wolfel ${ }^{5}$, \\ Oleksii Sergiiovych Solodiankin ${ }^{1}$, Anton Pavlovych Gerilovych ${ }^{1}$ \\ ${ }^{1}$ Department of Molecular Epizootology and Diagnostics, \\ National Scientific Center Institute of Experimental and Clinical Veterinary Medicine of the NAAS of Ukraine, \\ 61023 Kharkiv, Ukraine \\ ${ }^{2}$ SI Kharkiv Oblast Laboratory Centre of the MoH of Ukraine, Pomirky, 61070 Kharkiv, Ukraine \\ ${ }^{3}$ SI Mykolaiv Oblast Laboratory Centre of the MoH of Ukraine, 54058 Mykolaiv, Ukraine \\ ${ }^{4}$ SI Dnipropetrovsk Oblast Laboratory Centre of the MoH of Ukraine, 49064 Dnipro, Ukraine \\ ${ }^{5}$ Department of Bacteriology and Toxicology, Bundeswehr institute of Microbiology, 80937 Munich, Germany \\ Oksana.ceratium@gmail.com
}

Received: June 3, 2019

Accepted: January 17, 2020

\begin{abstract}
Introduction: Tularaemia is a zoonotic disease caused by the gram-negative bacterium Francisella tularensis, which is endemic to Ukraine. The aim of this work was to provide screening of different field samples (rodent tails, ticks, pellets, water, and hay) to obtain an actual picture of the tularaemia epizootic situation in the Kharkiv, Dnipropetrovsk, and Mykolaiv oblasts. Material and Methods: Samples were collected using the flag method (for ticks) and break-back traps (for rodents). Also, hay, water and owl pellets were collected for study. The $F$. tularensis genetic material in samples was detected using a 16S qPCR. Results: It was found that in Kharkiv oblast, $23 \%$ of collected samples were positive for $F$. tularensis, in Dnipropetrovsk oblast $1.9 \%$, and in Mykolaiv oblast $0.4 \%$. Conclusion: Among the sample types, $34.7 \%$ of ticks, $1.8 \%$ of rodents, and $36.4 \%$ of pellets were positive for $F$. tularensis. The most frequent carriers of $F$. tularensis were the D. reticulatus and I. ricinus ticks $(74.2 \%$ and $29.3 \%$, respectively, of positive results).
\end{abstract}

Keywords: Francisella tularensis, tularaemia, surveillance, PCR, Ukraine.

\section{Introduction}

Tularaemia is a zoonotic disease caused by the gram-negative bacterium Francisella tularensis. It occurs naturally in lagomorphs (rabbits and hares), rodents, especially microtine rodents such as voles, vole rats, and muskrats, beavers, and a wide variety of other mammals. Also, F. tularensis can be found in birds, amphibians, and invertebrates. It can also be transmitted by arthropod vectors such as deerflies and hard ticks of the Ixodidae family (22).
Tularaemia outbreaks in Ukraine have been known since the end of the 1940s with cases of human infection and high morbidity in almost every region of the country. These outbreaks were connected with the growth of rodent populations near sugar factories, human contact with animal carcasses in fur production, and tick bites. Then, after mass preventive measures, the outbreaks stopped in the 1960s (20). Since that time, mostly merely isolated cases and small outbreaks have occurred among humans, but the epizootological situation has remained adverse. Natural foci of 
tularaemia are present in 23 out of 25 oblasts and cover the main landscapes and geographical zones $(10,16,19)$. Kharkiv oblast is located in forest-steppe and steppe areas and Dnipropetrovsk and Mykolaiv oblasts are true steppe areas. Their favourable biotopes for rodent habitation are mostly similar: upland deciduous forests and pinewood terraces are typical for the woody parts of Kharkiv oblast and floodplains, fields, shelterbelts and ravine forests are typical for all three oblasts. The dominant species of rodents here are Myodes glareolus, Sylvaemus tauricus, Sylvaemus sylvaticus, and Sylvaemus uralensis. The natural foci of tularaemia correlate with the most stable floodplain populations of rodents. Haystacks are major sites of winter epizootic tularaemia outbreaks, but during the recent past, they have ceased to play such a large role as they formerly did due to a decline in agricultural farming in the Kharkiv area; however, haystacks are still relevant rodent habitats in Dnipropetrovsk and Mykolaiv oblasts. Other places that can contribute to rodent population density (fields, shelterbelts, etc.) witness sporadic seasonal outbreaks $(9,14,15,17)$. The role of the lagomorph Lepus europaeus seemed to be highly integral in former times, as this species is highly mobile, fertile, and long-lived. In former times hares were also carriers of $F$. tularensis, because Ixodidae ticks feed successfully on hares in all stages of life. However, nowadays, its populations are much diminished because of steppe zone ploughing (19).

As mentioned above, tularaemia can be spread by hard ticks. In the regions studied there are six species present that are important in tularaemia transmission: Ixodes ricinus, Dermacentor reticulatus, Dermacentor marginatus, Haemaphysalis punctata, Hyalomma plumbeum, and Rhipicephalus rossicus. The public health centre of Ukraine reported that the ticks of the Dermacentor genus carry $F$. tularensis more often than hard ticks of other genera, and D. reticulatus seems to be the most important vector among ticks in Ukraine $(1,2,10,18,22)$.

DNA and antigens of $F$. tularensis from infected owl prey persist in owl pellets for quite a long time. They can be detected using PCR and serological methods, and therefore pellets are promising material for epidemiological surveillance studies of tularaemia natural foci $(6,11,21)$. Owls have always inhabited Ukrainian territory, but nowadays they are under protection as their number is decreasing because of destruction of their natural habitats. Nevertheless, Strix aluco, Asio flammeus, Otus scops, and Athene noctua are typical owls that are still encountered on Ukrainian territory $(3,4,5,24)$.

The reasons for tularaemia outbreaks are still unclear, but continuous data collection on the status of known and suspected foci is important for prognoses and managing outbreaks (22). Therefore, the aim of our work was to screen different field samples (rodent tails, ticks, pellets, water, and hay) using PCR to obtain an actual picture of the tularaemia epizootic situation in Kharkiv, Dnipropetrovsk, and Mykolaiv oblasts.

\section{Material and Methods}

Sampling. Different material from Kharkiv, Dnipropetrovsk, and Mykolaiv oblasts was collected by the flag method. It included Ixodidae ticks $(\mathrm{n}=216)$ of three species: Ixodes ricinus $(\mathrm{n}=140)$, Dermacentor reticulatus $(\mathrm{n}=31)$, and Dermacentor marginatus $(\mathrm{n}=45)$. The species and sex were recognised using species qualifiers (8).

The break-back trapping method was used for rodent sampling using 400 trap/days. Traps were positioned in woods, floodplains, fields, and other locations to get high biodiversity in samples. The species and sex of trapped rodents were determined. The whole tail, or 1-2 mm of its thickest part if tails were pooled, was put into $1.5 \mathrm{~mL}$ Eppendorf reaction tubes with $500 \mu \mathrm{L}$ of sodium dodecyl sulphate (SDS) lysis buffer (50 mM of Tris- $\mathrm{HCl}, \mathrm{pH} 8.0 ; 200 \mathrm{mM}$ of $\mathrm{NaCl} ; 100 \mathrm{mM}$ of ethylenediaminetetraacetic acid (EDTA); and 1\% SDS) and then delivered to the laboratory. Rodent sampling was undertaken under the routine annual surveillance studies of Oblast Laboratory Centres of the $\mathrm{MoH}$ of Ukraine according to the ethical regulations.

Owl pellets $(n=25)$ were collected under owls' habitats or directly from owleries and hollows. In addition, environmental samples (water and hay, $\mathrm{n}=9$ ) were collected from the surroundings.

Rodent tail preparation before extraction. Before extraction, the rodent tails were homogenised. Proteinase K $(20 \mathrm{mg} / \mathrm{mL})$ in a $10 \mu \mathrm{L}$ volume was added to cut tails with SDS lysis buffer in $1.5 \mathrm{~mL}$ Eppendorf reaction tubes. Samples were incubated at $55^{\circ} \mathrm{C}$ and periodically vortexed until they became lysed. After lysis, samples were centrifuged at $13,000 \mathrm{rpm}$ for $5 \mathrm{~min}$. Then, the supernatant was collected for the next step of nucleic acid extraction. In some cases, starting material was prepared as a homogenous suspension of rodent organs (1-2 mm parts of the spleen, lungs, and heart) in $0.9 \%$ saline solution.

Tick preparation before extraction. At first, ticks were frozen at $-70^{\circ} \mathrm{C}$ for $30 \mathrm{~min}$ and subsequently put into $1.5 \mathrm{~mL}$ Eppendorf reaction tubes with physical saline solution and crushed with a pointed glass stick.

Extraction of total nucleic acids from samples. For nucleic acid extraction, the solid-phase method was used. A total of $100 \mu \mathrm{L}$ of sample (or $0.25 \mathrm{~g}$ of solid sample) was added to $300 \mu \mathrm{L}$ of lysis buffer ( $8 \mathrm{M}$ of guanidine thiocyanate (GuSCN), $80 \mathrm{mM}$ of Tris- $\mathrm{HCl}$, $35 \mathrm{mM}$ of EDTA, and $2 \%$ Triton $\times 100, \mathrm{pH} 8$ ) and heated up to $65^{\circ} \mathrm{C}$ for $5 \mathrm{~min}$. If necessary, rodent tail samples were centrifuged for $5 \mathrm{~min}$ at 13,000 rpm after lysis. The resulting supernatant was used for further extraction steps, which began with the addition to it of $25 \mu \mathrm{L}$ of sorbent $(100 \%$ silica water solution and $9 \mathrm{mM}$ of $\mathrm{HCl})$, 
and the solution was then vortexed for $1 \mathrm{~min}$ and centrifuged for $45 \mathrm{~s}$ at $10,000 \mathrm{rpm}$. Supernatant was discarded. Next the pellet was washed with $300 \mu \mathrm{L}$ of washing buffer no. 1 ( $8 \mathrm{M}$ of GuSCN, $80 \mathrm{mM}$ of Tris$\mathrm{HCl}, 35 \mathrm{mM}$ of EDTA, and $2 \%$ Triton $\times 100$, $\mathrm{pH}$ 8). Samples were centrifuged for $45 \mathrm{~s}$ at 10,000 rpm, and the supernatant was discarded. The pellet was washed twice with $500 \mu \mathrm{L}$ of washing buffer no. 2 (70\% EtOH mixed with $10 \mathrm{mM}$ of $\mathrm{NaCl})$, briefly vortexed, and centrifuged for $45 \mathrm{~s}$ at $10,000 \mathrm{rpm}$. After discarding the supernatant, the pellet was washed with $400 \mu \mathrm{L}$ of washing buffer no. 3 (chloroform mixed with isopropanol in the ratio $1: 2$ ), vortexed, and centrifuged for $45 \mathrm{~s}$ at $10,000 \mathrm{rpm}$. The supernatant was discarded and samples were incubated at $65^{\circ} \mathrm{C}$ until the sorbent became dry. For elution, $100 \mu \mathrm{L}$ of deionized water was added to the sorbent and the solution was incubated at $65^{\circ} \mathrm{C}$ for $5 \mathrm{~min}$. Samples were centrifuged for $2 \mathrm{~min}$ at $13,000 \mathrm{rpm}$ and the supernatant with extracted nucleic acids was transferred to a fresh Eppendorf reaction tube.

PCR. For the real-time PCR assay the Fran16S primer system was used: F: 5'-gAgCgCAACCCCTA TTgATA-3'; R: 5'-TTTTTgAgTTTCgCTCCAgCT-3'; Probe: 6FAM-CTATTgAgACTgCCgCTgACAAggC $\mathrm{BBQ}$, enabling an amplicon product of $184 \mathrm{bp}$ to be obtained. The $F$. tularensis sbsp. holarctica vaccine strain 15 NIIEG was used as a positive DNA template. The final volume of the reaction mixture was $25 \mu \mathrm{L}$ and was comprised of AmpliTaq Gold DNA Polymerase (Applied Biosystems, Foster City, CA, USA) 1.25 U/50 $\mu \mathrm{L}$, PE-Buffer 1X, deoxyribonucleotide triphosphate (dNTP) mix $0.2 \mathrm{mM}, \mathrm{MgCl}_{2} 1.5 \mathrm{mM}$, primer $\mathrm{F} 10 \mathrm{pM}$, primer $\mathrm{R} 10 \mathrm{pM}$, probe $5 \mathrm{pM}$, and carboxyrhodamine (ROX) $0.01 \mu \mathrm{M}$. Either $5 \mu \mathrm{L}$ of extracted DNA or $5 \mu \mathrm{L}$ of PCR-grade water was used as a template (the latter for the no-template-control reactions). Thermal cycling was performed using a 7500 Fast cycler (Applied Biosystems, USA) on the following program: one cycle at $95^{\circ} \mathrm{C}$ for $5 \mathrm{~min}$ for Hot Start Taq activation, followed by 40 cycles at $95^{\circ} \mathrm{C}$ for $15 \mathrm{~s}$ for denaturation, $58^{\circ} \mathrm{C}$ for $30 \mathrm{~s}$ for annealing, and $72^{\circ} \mathrm{C}$ for $40 \mathrm{~s}$ for extension, and a final elongation step at $72^{\circ} \mathrm{C}$ for $1 \mathrm{~min}$. A fluorescence reading was taken at every $72^{\circ} \mathrm{C}$ step. Results were visualised in $1.5 \%$ agarose gel.
Data analysis. Data analysis was carried out using Microsoft Excel. A correspondence plot was generated by using the free PAST software [25].The locations of samples collection were mapped using qGIS free software (26).

\section{Results}

PCR. The qPCR detection of $F$. tularensis conserved rRNA regions was performed with the Fran16S primer system, but all samples were also checked in agarose gel, to avoid false negative results in cases of small amounts of $F$. tularensis genetic material (Fig. 1).

Kharkiv oblast. In the Kharkiv oblast, 380 samples were collected in total (183 rodent tails, 181 ticks, 15 pellets, and 1 water sample). Twenty-three percent of them were positive for $F$. tularensis $(88$ samples): $19.2 \% \quad(74$ samples $)$ of ticks, $2.6 \%$ (10 samples) of rodent tails, and 1\% (4 samples) of Strix aluco pellets. Samples were collected from Valky (52 samples), Kharkiv (53 samples), the Kharkiv region (16 samples), Balakliya (45 samples), Dergachi (55 samples), Zmyiv (61 samples), Krasnokutskiy (41 samples), Pechenizkiy (4 samples), and Bogoduchiv (53 samples). Positive results were found in Gazove village, Bogodukhiv region (48 positive samples); Rai Olenivka village, Kharkiv region (10 positive samples); Kreidyanka village, Balakliyskii region (10 positive samples); Gomolsha National Nature Park, Zmiiv region (15 positive samples); Kharkiv wood park (4 positive samples); the Valky region, and Perekip village (1 sample each) (Fig. 2).

The samples were collected from different field material, and the highest percentage of positives was shown in the Ixodidae ticks Ixodes ricinus, Dermacentor reticulatus, and Dermacentor marginatus. Also, some positive results were found in Mus musculus, Apodemus agrarius, and Myodes glareolus, and in Strix aluco pellets (Fig. 3). No correlation between sex and risk of tularaemia infection in species was found.

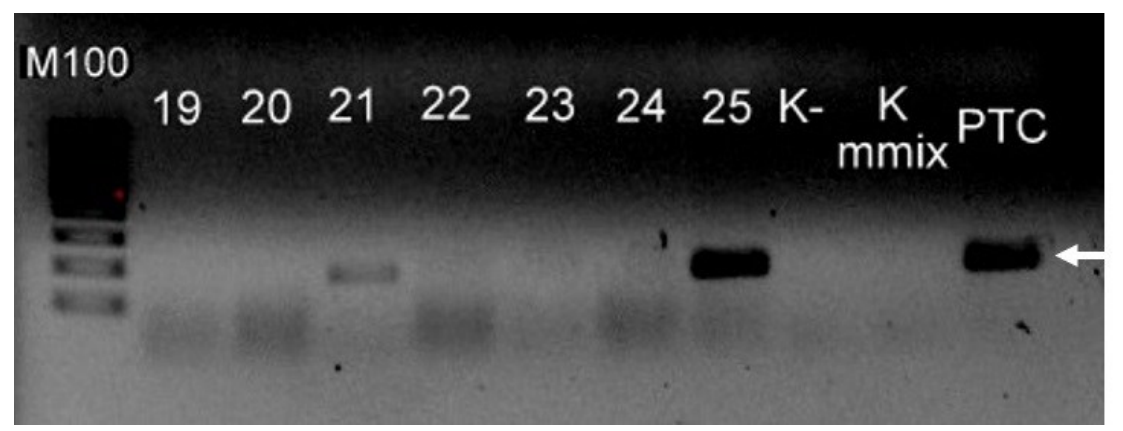

184·b.p.

Fig. 1. Example of detection of $F$. tularensis genetic material using Fran $16 \mathrm{~S}$ primer systems M 100 - molecular weight marker; $19-24$ - rodent tails (21 is positive); $25-$ D. reticulatus (positive); $\mathrm{K}-$ - negative control; Kmmix - mastermix negative control, PTC - positive control (LVS 15 NIIEG) 
Dnipropetrovsk oblast. For this study, 105 samples were collected in the Dnipropetrovsk oblast from two regions: Petropavlivskyi (67 samples) and Pjatichatki (38 samples). Only two samples (1.9\%) showed a positive PCR result: a rodent tail sample of Apodemus agrarius collected in the Pjatichatki region near Chervona poliana village and a Dermacentor marginatus tick sample collected in the Petropavlivskyi region near Petripavlilka village (Fig. 4).

In total, 105 samples were collected: rodent tails (52 samples), Dermacentor marginatus ticks (35 samples), Strix aluco pellets (10 samples), water (6 samples), and hay (2 samples) (Fig. 5). No correlation between sex and risk of tularaemia infection in tested species was detected.

Mykolaiv oblast. In the Mykolaiv oblast 501 samples were collected from seven regions: Voznesinskiy (190 samples), Vitovskiy (106 samples), Pervomaiskiy (101 samples), Snigurivskiy (62 samples), Kryvoozerivskiy (34 samples), Ochakiv (4 samples), and Berezneguvaty (4 samples) (Fig. 6).

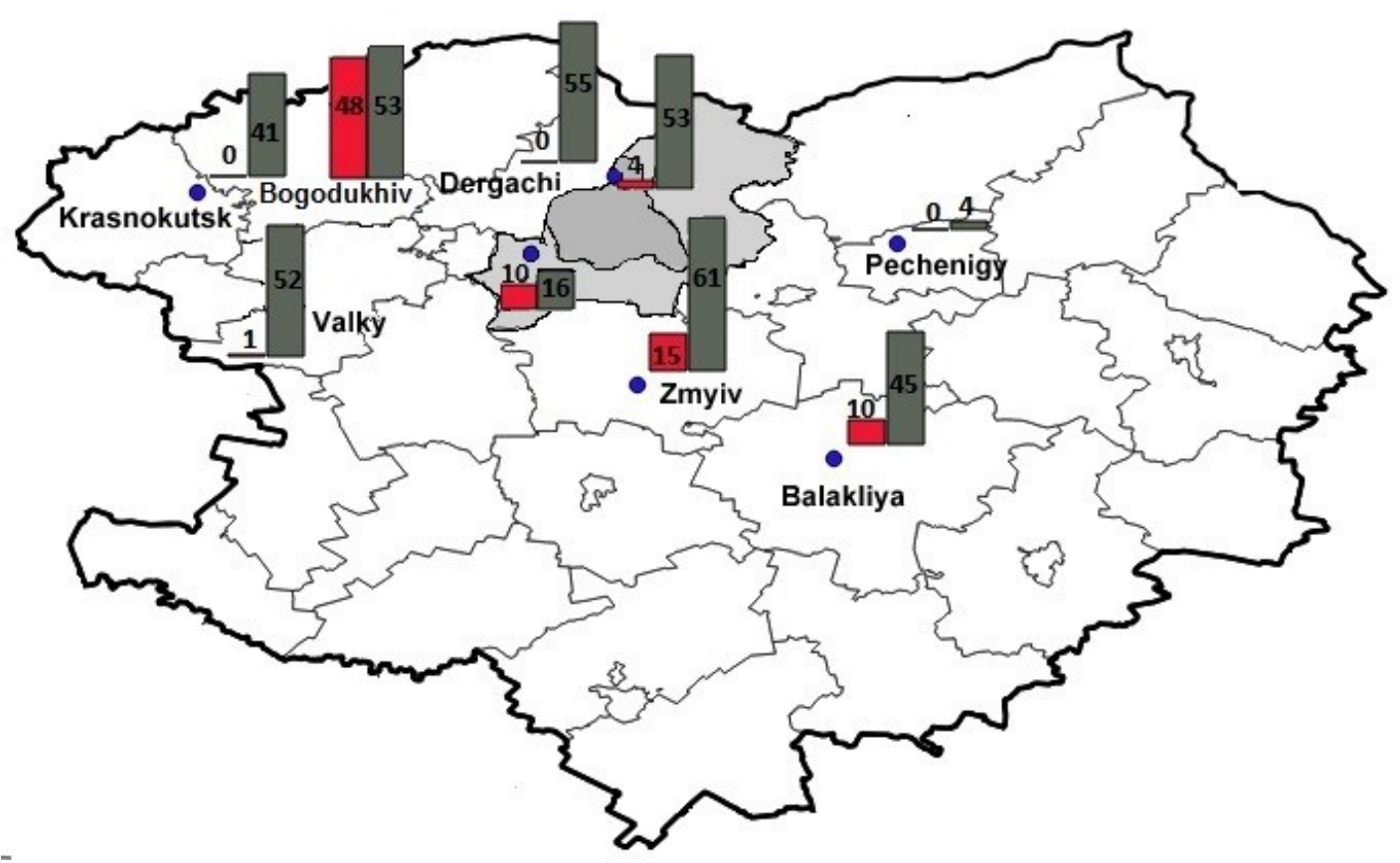

Fig. 2. Geographical location of sampling areas in Kharkiv oblast (samples are grouped by regions). Kharkiv and the Kharkiv region are marked in grey. Positive samples are marked in red and the total quantity of samples is marked in grey

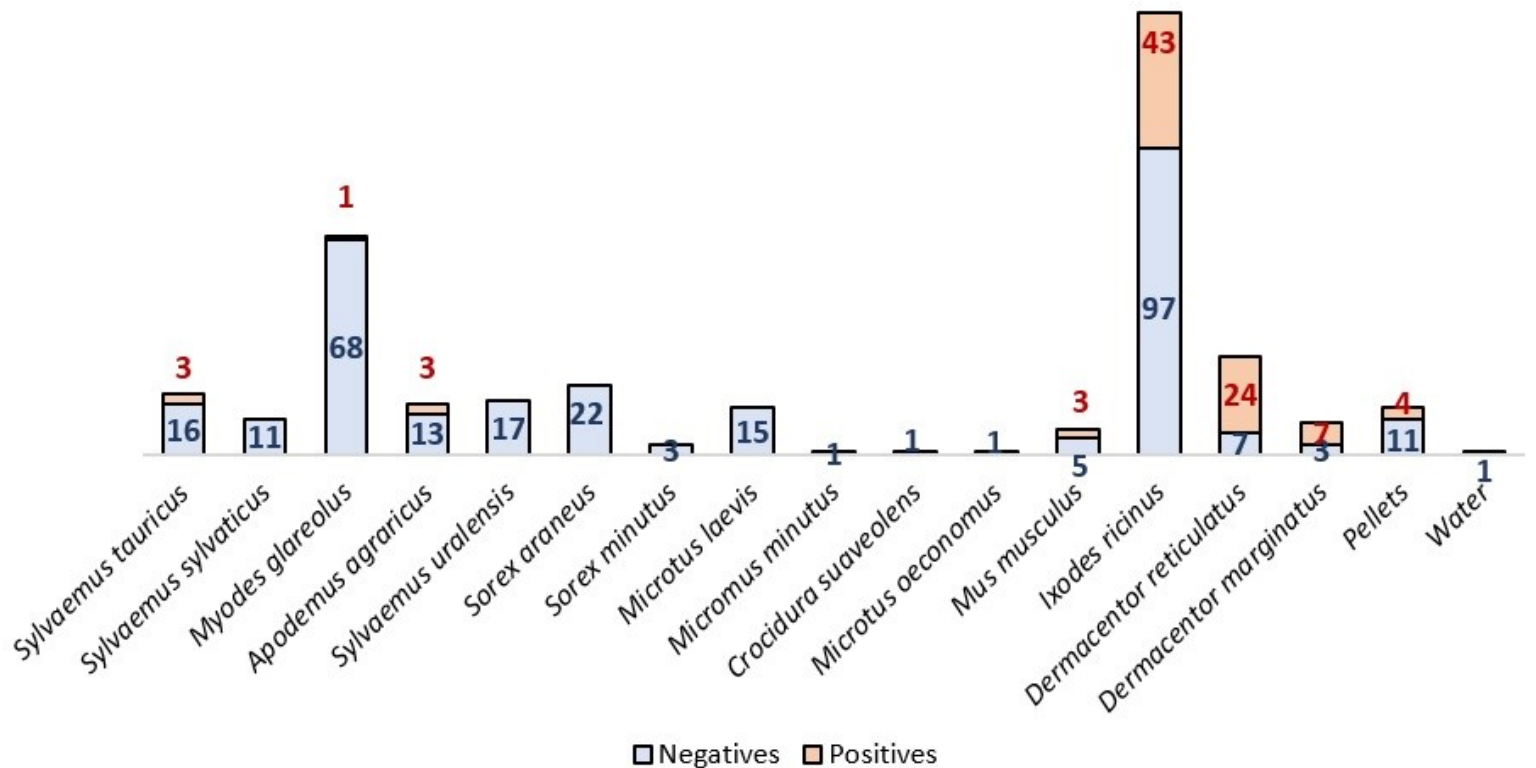

Fig. 3. The distribution of collected samples by species and type in Kharkiv oblast. The quantity of positive samples is marked on the graph in red and the quantity of negative samples is marked in blue 


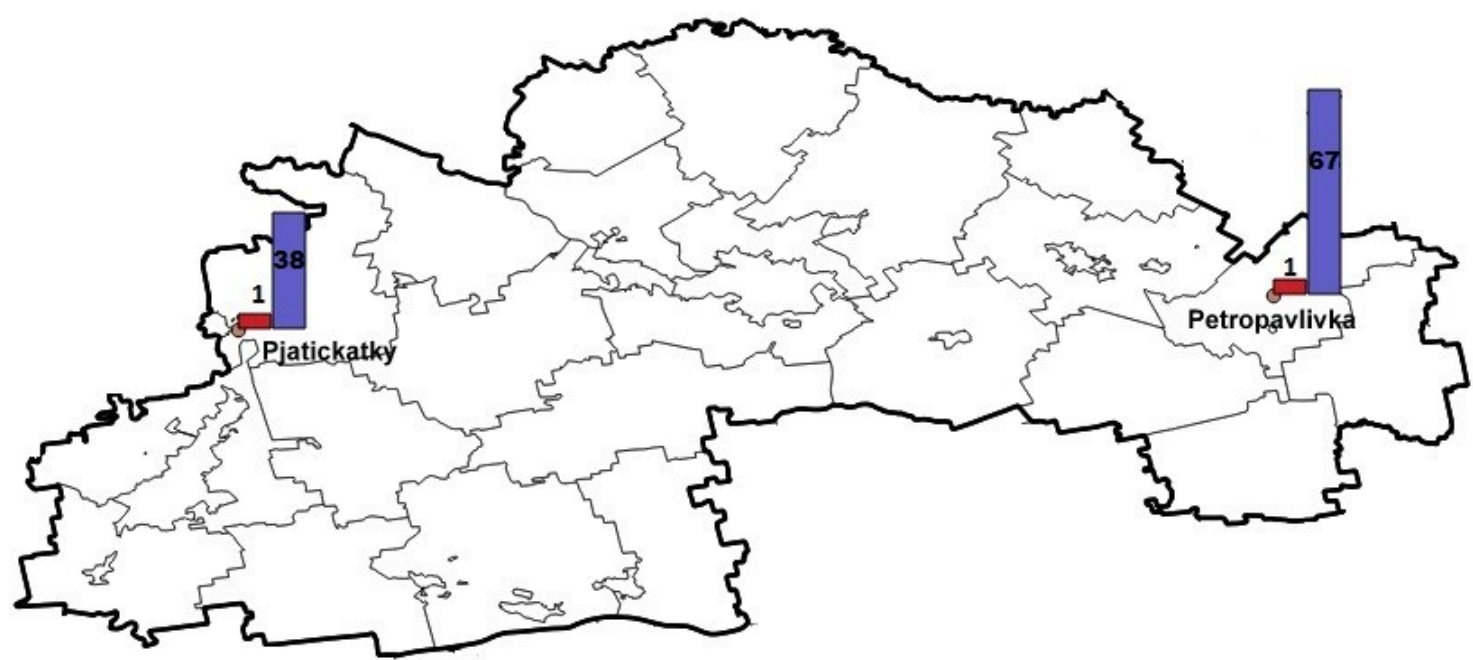

Fig. 4. Geographical location of sampling areas in Dnipropetrovsk oblast (samples are grouped by regions). Positive samples are marked in red and the total quantity of samples is marked in blue

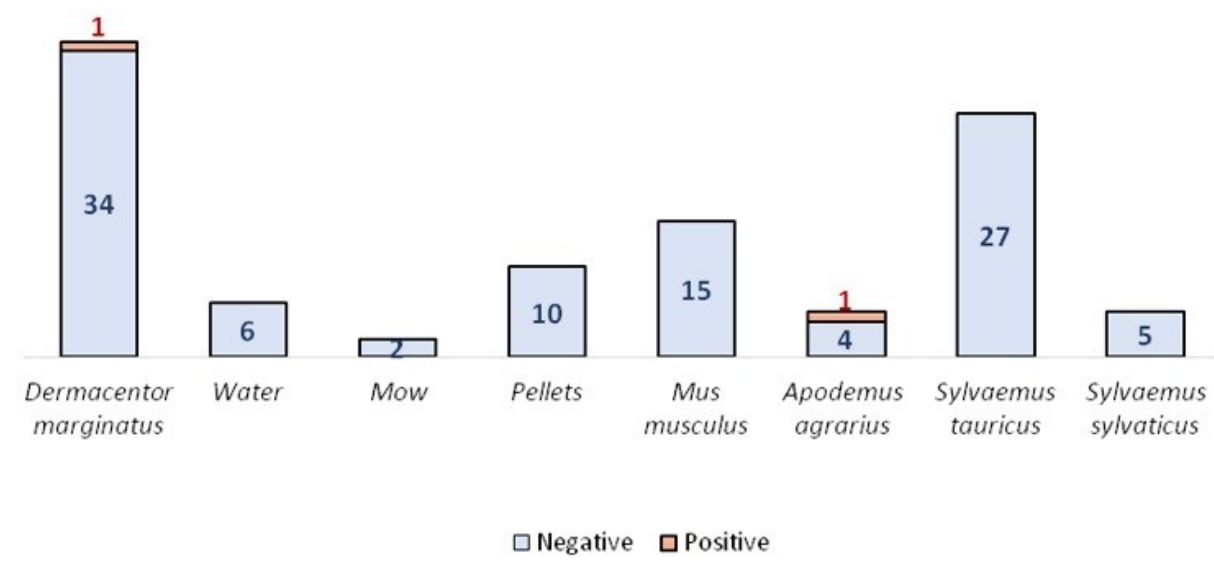

Fig. 5. The distribution of collected samples by species and type in Dnipropetrovsk oblast. The quantity of positive samples is marked on the graph in red and the quantity of negative samples is marked in blue

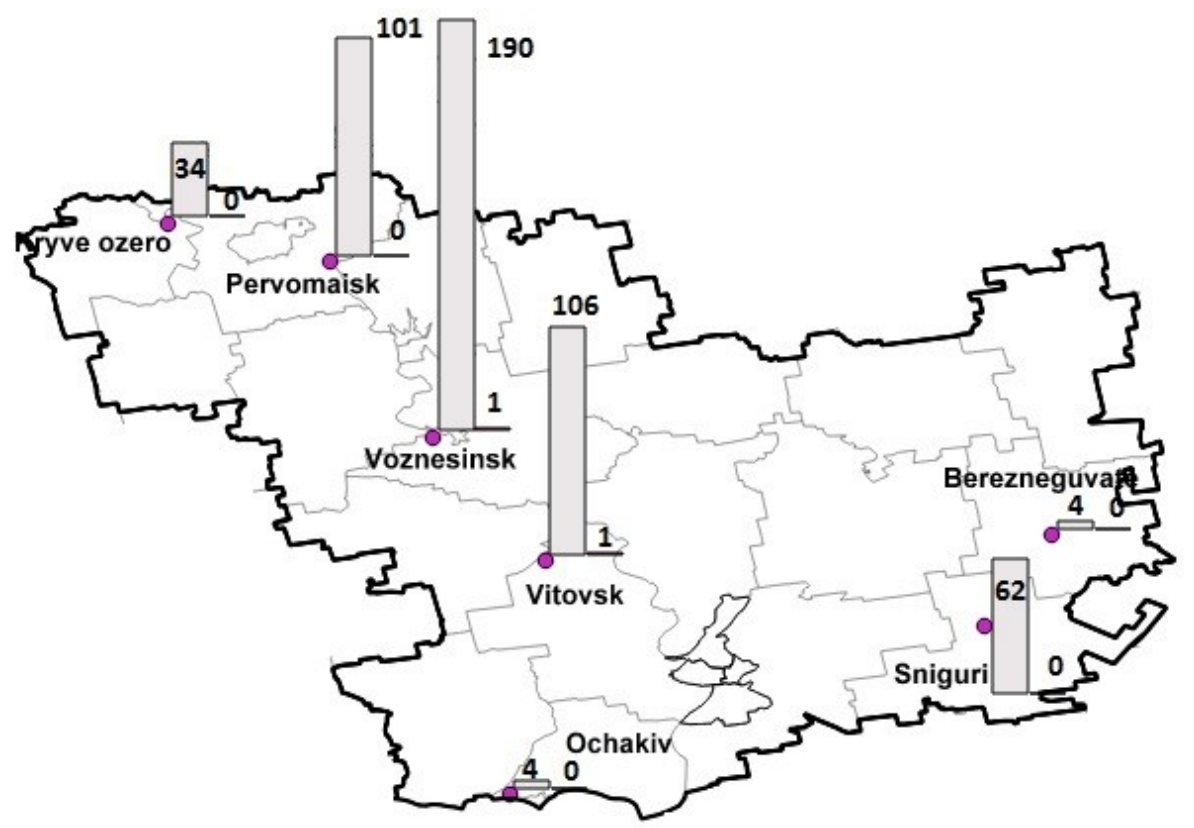

Fig. 6. Geographical location of sampling areas in Mykolaiv oblast (samples are grouped by regions). Positive samples are marked in red and the total quantity of samples is marked in grey 
The positive samples were detected from Mus musculus, collected in Bashtanka village, Voznesinskii region (1 sample), and from Sylvaemus sylvaticus, collected in Zelenyi Gai village, Vitovskii region (1 sample).

Only rodent tails and homogenate of organs were collected from this oblast, and two samples showed positive results $(0.4 \%)$. The positive samples were from Sylvaemus sylvaticus and Mus musculus and were collected in Zalenyi Gai village, Vitovskiy region and in Bashtanka village, Voznesinskiy region (Fig.7). No correlation between sex and risk of tularaemia infection in species could be observed.

Correspondence analysis. We provided the correspondence analysis of all our data from all studied regions to evaluate which species of animal or tick or material may carry F. tularensis more often (Fig. 8).
The closer the sample type name to the "positive" label, the higher the detection frequency of F. tularensis in that sample type. Axis 1 coordinates show the weighted distances between different species and groups, shown on a bed plot with dots. The other types of samples are Mus spicilegus, Crocidura suaveolens, Cricetulus migratorius, S. uralensis, Microtus laevis, Sorex araneus, S. minutus, Micromys minutus, Microtus oeconomus, water, and hay.

The correspondence analysis of our study showed, that Ixodidae ticks, especially $D$. reticulatus and I. ricinus, are more likely to be carriers of tularaemia infection than rodents. Pellets can also be assumed to be material that often carries $F$. tularensis and is reliable for surveillance studies, but the panel was too small $(\mathrm{n}=11)$ to make strict conclusions.

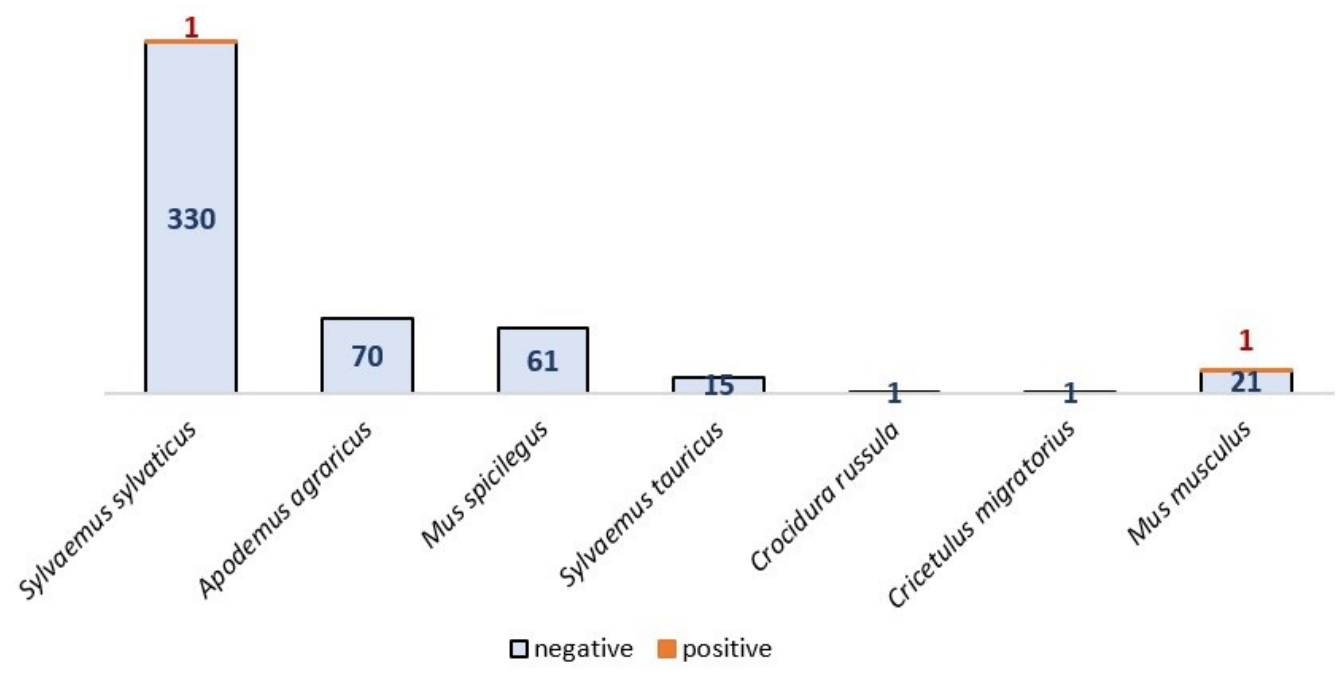

Fig. 7. The distribution of collected samples by species and types in Mykolaiv oblast. The quantity of positive samples is marked on the graph in red and the quantity of negative samples is marked in blue

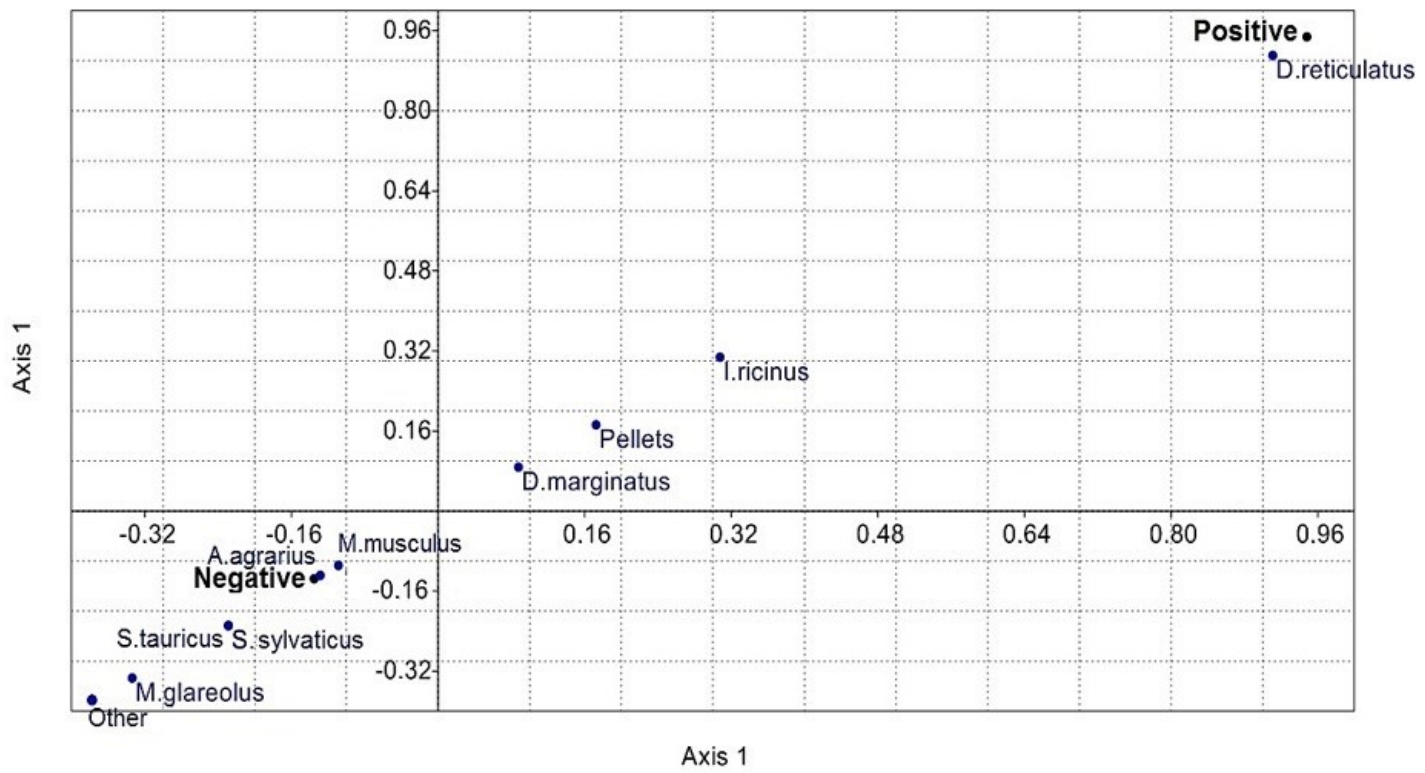

Fig. 8. The result of correspondance analysis (CA) for all samples grouped by species or material type 


\section{Discussion}

Ukraine, as a country of the Northern Hemisphere, is endemic for tularaemia. In the Kharkiv oblast at least six foci of tularaemia are known, e.g. Zmiiv, Balakliya, Izum, Velykui Burluk, Sachnovsk, and Kharkiv regions. In this oblast the last case of human tularaemia infection was recorded in 2003. The main infection carriers here are Mus musculus and Microtus arvalis (official data from Kharkiv Oblast Laboratory Centre).

In contrast, the Dnipropetrovsk oblast is the region where no natural foci of tularaemia was registered. This was the case despite the geographical location of this oblast and its landscape with rivers and fields making it very suitable for infection spread. The absence of tularaemia cases among humans and rare cases in animals made this region interesting for this prevalence study (official data from Dnipropetrovsk Oblast Laboratory Centre).

As a higher prevalence region, the Mykolaiv and Odessa oblasts are a counterpoise to Dnipropetrovsk. In 1997-1998, up to 100 cases of human tularaemia infection were registered in these oblasts. This outbreak was connected with lagomorphs and rodents that lived in woodland belts. However, it was not connected with areas where known foci of tularaemia had been located. A very recent case of human tularaemia infection was detected in the Voznesinskii region, which was probably connected with tick transmission (official data from Mykolaiv Oblast Laboratory Centre).

PCR is known as a rapid and highly sensitive method of pathogen genome detection in different types of samples. It can be used for studying pathological material, vectors for vector-borne infections, pellets, and environmental samples, including water, mud, etc. In our study, we used Ixodidae ticks, owl pellets, water, and hay, which are routine samples for the study of tularaemia (22), and are safe types of material for sampling and follow-up work. Rodents are known carriers of tularaemia that play a leading role in natural foci formation. For tularaemia detection in rodents, usually organs with $F$. tularensis tropism are taken for analysis, to obtain high concentrations of $F$. tularensis material, and those organs can be the spleen, lungs, heart or a combination. However, the autopsy of tularaemiainfected animals is a hazardous procedure that needs special equipment, laboratory structure, and permission. Thus, for biosafety and biosecurity reasons, we decided to perform PCR analysis of rodent tails, as the PCR method allows even a single copy of genetic material to be detected in a sample. Some samples that came from oblast laboratory centres as prepared organ homogenates also were included in this study. Our study showed that rodent tails are valid material for $F$. tularensis detection using PCR, and can be used if autopsies are impossible.

The most recent case of human tularaemia infection in the studied regions was detected in 2018, when a man was infected with $F$. tularensis in Oleksandrivka village, Voznesinskii region, Mykolaiv oblast. The Mykolaiv
Oblast Laboratory Centre reported finding antitularaemia antibodies in ticks from that region. In our study however, we could not find genetic material of $F$. tularensis in rodent tails or organ homogenates collected from Oleksandrivka village, but we did find one positive sample from the neighbouring Bashtanka village in the Voznesinskii region.

A very high percentage of positive samples $(90.6 \%$, 48 positive out of 53 collected) was found in Gazove village, Bogodukhiv region, Kharkiv oblast. However, that this place is an active focus of tularaemia is no easy assumption. Only ticks were sampled from this place, and $51 \%$ of them belonged to the Dermacentor genus. The epidemiology of tularaemia is still unclear, but Ixodidae ticks and especially Dermacentor spp. are more common $F$. tularensis carriers than other potential carrier organisms. This has been known about the Ukrainian situation since 1964, when Stupnitskaya et al. (20) reported that D. reticulatus and I. ricinus ticks are among the main carriers and reserves of tularaemia infection, together with water rats. Hightower et al. (10) reported in their study with Oblast Laboratory Centres that out of a total of 2,400 F. tularensis-positive samples, $25.5 \%$ were isolated from $D$. reticulatus, $12.7 \%$ from D. marginatus, $5.8 \%$ from I. ricinus, and $22 \%$ from all rodents of a 23 -species group. There are a series of D. reticulatus and $I$. ricinus studies on tularaemia presence in neighbouring Poland and the Czech Republic, which show the high rate of $F$. tularensis especially in $D$. reticulatus, and the lower rate in I. ricinus $(12,13,23)$. Studies in Georgia (7) showed Dermacentor ticks to also be notable $F$. tularensis carriers (in Georgia, D. marginatus is the predominant species instead of $D$. reticulatus), but $I$. ricinus ticks do not play such a large role in as they do in Ukraine. It is interesting that $F$. tularensis was isolated most often from $M$. arvalis rodents. Although this species was unfortunately not included in our study, M. arvalis is also a known carrier of tularaemia in Ukraine. Thus, to compare our study with others, we provided the correspondence analysis for all samples to see which types are more likely to carry $F$. tularensis. Our data showed that Ixodidae ticks, and especially D. reticulatus and I. ricinus, act as infection carriers more often than rodents. Nevertheless, the study of tularaemia circulation in rodents is also desirable for better understanding of the epidemiological process engendered at this position in the biome. Pellets are also shown as material with a high probability of tularaemia agent detection. However, the sampling in our study is very heterogenous, and the study includes some species (e.g. M. oeconomus) and types of material (e.g. hay) that were collected in small amounts. So we need more data to perform deep analysis and draw correct conclusions.

Tularaemia is numbered among the infectious diseases common to humans and animals, and is a matter of interest in the context of public health. Surveillance studies of wildlife are required for tularaemia natural foci identification, prognosis, and 
provision of measures for outbreak prevention. In our study, the Kharkiv $(\mathrm{n}=380)$, Dnipropetrovsk $(\mathrm{n}=105)$, and Mykolaiv $(\mathrm{n}=501)$ oblasts were the areas of interest, where we collected material potentially infected or contaminated with $F$. tularensis: rodent tails $(\mathrm{n}=736)$, ticks $(\mathrm{n}=216)$, pellets $(\mathrm{n}=25)$, water $(\mathrm{n}=7)$, and hay $(n=2)$. In the Kharkiv oblast $23 \%$ of collected samples were positive, in the Dnipropetrovsk oblast $1.9 \%$ of collected samples were, and in the Mykolaiv oblast $0.4 \%$ of samples were positive for $F$. tularensis. However, such a high percentage of positive samples in the Kharkiv oblast could be explained not only by the presence of foci but also by a differently constituted Kharkiv sample pool, especially with regard to the extensive sampling of ticks $(n=181)$ from this area. Thus, the correspondence analysis of sample species and groups confirmed that the most frequent carriers of $F$. tularensis were the D. reticulatus and I. ricinus ticks: $74.2 \%$ and $29.3 \%$, respectively, were positive. Because of the exigencies of biosafety, we provided a trial of the safe sample which is the rodent tail for the study of $F$. tularensis using PCR, and we think that this is an appropriate substitute for rodent organ study if the autopsy of the animal is impossible for any reason. The epidemiological data that are currently available cannot show the whole picture of tularaemia ecology in Ukraine. The monitoring of known natural foci and the search for new ones must be incessant if we are to deepen knowledge of tularaemia epidemiological processes in Ukraine.

Conflict of Interests Statement: The authors declare that there is no conflict of interests regarding the publication of this article.

Financial Disclosure Statement: This research was funded by the project number 16.9072.6-007.04 (Ukrainian-German biosecurity initiative on zoonosis risk management at the EU external borders).

Animal Rights Statement: The experiments were conducted in accordance with the local Ethical Committee laws and regulations.

\section{References}

1. Akimov I.A., Nebogatkin I.V.: Seasonal changes in activity, sex composition, and areal of the tick Ixodes ricinus (Acari, Ixodida) in the landscape-geographical regions of Ukraine. Vestnik Zoologii 2010, 44, e-19-e-25.

2. Akimov I.A., Nebogatkin I.V.: Distribution of ticks of the genus Dermacentor (Acari, Ixodidae) in Ukraine. Vestnik Zoologii 2010, 45, e-1-e-6.

3. Akulov A.Y., Atemasova T.A., Bartenev A.F., Viter S.G., Vlashchenko A.S., Zinenko A.I., Korshunov A.V., Saidahmedova N.B., Skorobogatov E.V., Shabanov D.A., Utevsky A.Yu.: To reorganization of zoning of the National Park "Gomilshanski Lisy”. Nature Reserves in Ukraine 2006, 12, 73-79.

4. Atemasova T.A., Atemasov A.A., Devyatko T.N., Chernikov V.F.: The bird fauna of oak forest in steppe ravines.
Proc Conf Study of Severskii Donets pool birds, Kharkiv, Ukraine, 2005, 13-18.

5. Chaplygina A.B., Savinska N.O., Zaritskaya U.P.: Peculiarities of the formation of the dwindling fauna in the mountainous otters of the North-Eastern Ukraine. Bilogiya Valeologiya 2009, 11, 109-115.

6. Dobrochotov B.P., Mecheriakova I.S., Rudnev M.M., Pylypenko V.G., Basylova G.I., Tarasov M.P.: Experience in studying tularaemia epizootology in the steppe outbreak of the Stavropol Territory by serological study of pellets. Problems Hazardous Infect 1975, 3, 176-180.

7. Elashvili E., Kracalik I., Burjanadze I., Datukishvili S., Chanturia G., Tsertsvadze N., Beridze L., Shavishvili M., Dzneladze A., Grdzelidze M., Imnadze P., Pearson A., Jason K.: Environmental monitoring and surveillance of rodents and vectors for Francisella tularensis following outbreaks of human tularaemia in Georgia. Vector Borne Zoonotic Dis 2015, 15, 633-636. doi: 10.1089/vbz.2015.1781.

8. Filippova N.A.: Ixodes ticks, subfamily Ixodidae. In: Fauna of the USSR, Leningrad, 1977, p. 396.

9. Gerasymenko N.P.: Quaternary deposits of Ukraine (forest-soil formation), VGL Obrii, Kyiv, 2017, 214.

10. Hightower J., Kracalik I., Vydayko N., Goodin D., Glass G., Blackburn J.: Historical distribution and host-vector diversity of Francisella tularensis, the causative agent of tularaemia, in Ukraine. Parasit Vectors 2014,7, 453-458. doi:10.1186/s13071014-0453-2.

11. Hornok S., Szoke K., Estok P., Krawczyk A., Haarsma A.J., Kovats D., Boldogh S.A., Morandini P., Szekeres S., Takacs N., Kontschan J., Meli M.L., Fernandez de Mera I.G., de la Fuente J., Gyuranecz M., Sulyok K.M., Weibel B., Gonczi E., de Bruin A., Sprong H., Hofmann-Lehmann R. Assessing bat droppings and predatory bird pellets for vectorborne bacteria: molecular evidence of bat-associated Neorickettsia sp. in Europe. Antonie van Leeuwenhoek 2018, 111, 1707-1717. doi:10.1007/s10482-018-1043-7.

12. Hubálek Z., Rudolf I.: Francisella tularensis prevalence and load in Dermacentor reticulatus ticks in an endemic area in Central Europe. Med Vet Entomol 2007, 31, 234-239. doi:10.1111/mve. 12229

13. Hubálek Z., Trem F., Halouzka J., Juricová Z., Hunady M., Janík V.: Frequent isolation of Francisella tularensis from Dermacentor reticulatus ticks in an enzootic focus of tularaemia. Med Vet Entomol 1996, 10, 241-246.

14. Mezhzherin S.V., Lashkova E.I., Tovpinets N.N.: Geographic distribution, population densities, and habitat preference of the wood mice genus Sylvaemus (Rodentia, Muridae) on the territory of Ukraine. Vestnik Zoologii 2002, 36, 39-49.

15. Naglov V.: The importance of small mammals in epizootic events of tularaemia in the Kharkiv region. Proc Theriological School 2014, 12, 47-55.

16. Nechoroshych Z.M., Gurbubayeva G.M., Pilipenko N.V., Protsyshina N.M., Parkhomenko N.B., Vidyba N.B., Kovbasyuk O.V., Yegorova O.O.: The genetic diversity of F. tularensis strains, isolated in different landscape-geographical zones of Ukraine. Proc 12th Ann Sci Pract Conf Modern problems of epidemiology, microbiology, hygiene and tuberculosis. Lviv, Ukraine, 2015, pp. 50-53.

17. Reva A.A.: Ecological characteristics of rodent populations in Prydniprovie woods. Biosystems Diversity 2003, 11, 208-213.

18. Rusev I.T.: Species structure, number and biotope distribution of ticks in the North-Western coast of the Black Sea. Visnyk Odesskogo Natsionalnogo Universitety 2009, 14, 89-101.

19. Rusev I.T., Mogilevsky L.A., Boshchenko Yu.A., Zakusylo V.N.: Biocenotic peculiarities of tularaemia natural aspects of Ukraine steppe zone. Visnyk Sumy State Univers 2005 , 7, pp. 25-35.

20. Stupnitskaya V.M., Marinov M.P., Litvinenko Ye.F., Slesarenko V.V., Slesarenko A.S., Khizhinskaya O.P., Stepanova I.A., Buyalo S.G.: Natural tularaemia foci on the territory of the 
Ukrainian SSR. Zhurnal Mikrobiol Epidemiol Immunobiol 1964, $10,94-98$

21. Velychko O., Vasiunets L., Semenyshyn O., Hasiy L.: Activity of natural tularaemia foci in West Ukraine. Proc ISDS Annual Conference, Atlanta, USA, 2016, e91.

22. WHO Guidelines on Tularaemia.: WHO Press, 2007. https://apps.who.int/iris/bitstream/handle/10665/43793/9789241 547376_eng.pdf;jsessionid $=$ 965A228F047A3DB3C57D04A7 11985A6A? sequence $=1$.

23. Wójcik-Fatla A., Zając V., Sawczyn A., Cisak E., Sroka J., Dutkiewicz J.: Occurrence of Francisella spp. in Dermacentor reticulatus and Ixodes ricinus ticks collected in eastern Poland. Ticks, Tick Borne Dis 2015, 6, 253-257. doi:10.1016/j.ttbdis.2015.01.005

24. Yatsyuk Y.A.: About tawny owl count techniques. Berkut 2005, $14,255-262$.

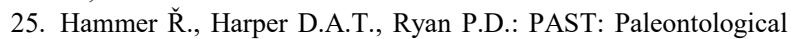
statistics software package for education and data analysis. Palaeontol Electron 2001, 4, 4.

26. QGIS Development Team: QGIS Geographic Information System. Open Source Geospatial Foundation Project. 2019. http://qgis.osgeo.org. 